Article

\title{
X-ray Structures of Succinimidyl Halobenzoates
}

\author{
Constantin Mamat ${ }^{1}$, Daniel Holger Weiß ${ }^{2}$ and Martin Köckerling ${ }^{2, *}$ \\ 1 Helmholtz-Zentrum Dresden-Rossendorf, Institut für Radiopharmazeutische Krebsforschung, \\ Bautzner Landstraße 400, D-01328 Dresden, Germany; c.mamat@hzdr.de \\ 2 Anorganische Festkörperchemie, Institut für Chemie, Universität Rostock, Albert-Einstein-Straße 3a, \\ D-18059 Rostock, Germany; daniel.weiss2@uni-rostock.de \\ * Correspondence: Martin.Koeckerling@uni-rostock.de; Tel.: +49-381-498-6390
}

Academic Editor: Martin T. Lemaire

Received: 10 February 2017; Accepted: 15 March 2017; Published: 20 March 2017

\begin{abstract}
The crystal and molecular structures of five succinimidyl halobenzoates are reported. Corresponding derivatives with the respective halo-radionuclide $\left({ }^{18} \mathrm{~F},{ }^{76} \mathrm{Br},{ }^{123} \mathrm{I} /{ }^{124} \mathrm{I} /{ }^{125} \mathrm{I} /{ }^{131} \mathrm{I}\right)$ were prepared and used for the radiolabeling of biologically active (macro-)molecules (peptides, proteins, antibodies) under mild labeling conditions. All compounds were crystalized from petroleum ether/ethyl acetate mixtures.
\end{abstract}

Keywords: building block; radiolabeling; $\left[{ }^{18} \mathrm{~F}\right] \mathrm{SFB} ; \mathrm{SIB} ; \mathrm{SBrB}$

\section{Introduction}

The radiolabeling of large biologically active molecules such as peptides, proteins or antibodies is an ongoing issue in radiopharmacy [1-5]. Harsh reaction conditions (high temperature, organic solvents, oxidizing conditions) for the introduction of the radionuclide and the selective radiolabeling, together with the sensitivity of the applied biomolecules are often the main problems. Thus, novel radiolabeling building blocks were elaborated for a selective and mild insertion of the radionuclide under physiological friendly conditions. Succinimidyl esters which belong to activated esters [6] play a major role for this purpose.

$\mathrm{mSIB}$, oSIB, and pSIB with radioiodine were first developed [7-10] and are the basis of all other (radio)halogenated succinimidyl esters described in this paper. They are important for labeling purposes with radioiodine $\left({ }^{123} \mathrm{I} /{ }^{124} \mathrm{I} /{ }^{125} \mathrm{I} /{ }^{131} \mathrm{I}\right)[11-20]$. [ $\left.{ }^{18} \mathrm{~F}\right] \mathrm{SFB}$ is the most applied building block in fluorine-18 chemistry. Additionally, a carbon-11-containing SFB derivative was synthesized in the past [21]. In the meantime, several commercial suppliers deliver the non-radioactive SFB compound. $\left[{ }^{76} \mathrm{Br}\right] \mathrm{SBrB}$ is rarely applied $[22,23]$.

In this paper, we synthesized the non-radioactive esters SFB 3a, SClB 3b, SBrB 3c, o-SIB 3d, and $p$-SIB $3 \mathbf{e}$ which are commonly in use as non-radioactive standards to analyze radiolabeling via TLC and HPLC analyses and determined the molecular structure of these compounds via single crystal XRD.

\section{Results and Discussion}

\subsection{Synthesis and Chemistry}

In general, the radiolabeling of biomacromolecules (peptides, proteins, and antibodies) follows a two-step procedure. Normally, these compounds were not directly radiolabeled. For this purpose, the radionuclide-containing building block was prepared first. In the case of radiofluorine ${ }^{18} \mathrm{~F}$, electron-demanding ethyl benzoates were applied $[24,25]$ and the fluorine was introduced via a nucleophilic substitution $S_{N} A r$ of the trimethylammonium group in most of the cases [2]. Newer developments are 
based on the use of iodonium salts [26,27] or nickel complexes [28] as precursors. Afterwards, the ethyl group was cleaved followed by the introduction of the succinimidyl group.

In the case of radiobromine and radioiodine, both radionuclides were classically inserted by an electrophilic substitution $S_{\mathrm{E}} \operatorname{Ar}$ (radiohalodestannylation) using stannyl precursors.

The second step involves the actual labeling of the (sensitive) biomacromolecule. Mostly, free amine groups were used for this labeling reaction under mild conditions (room temperature, aqueous solvents, non-oxidizing conditions, short reaction times). The overview is outlined in Scheme 1.

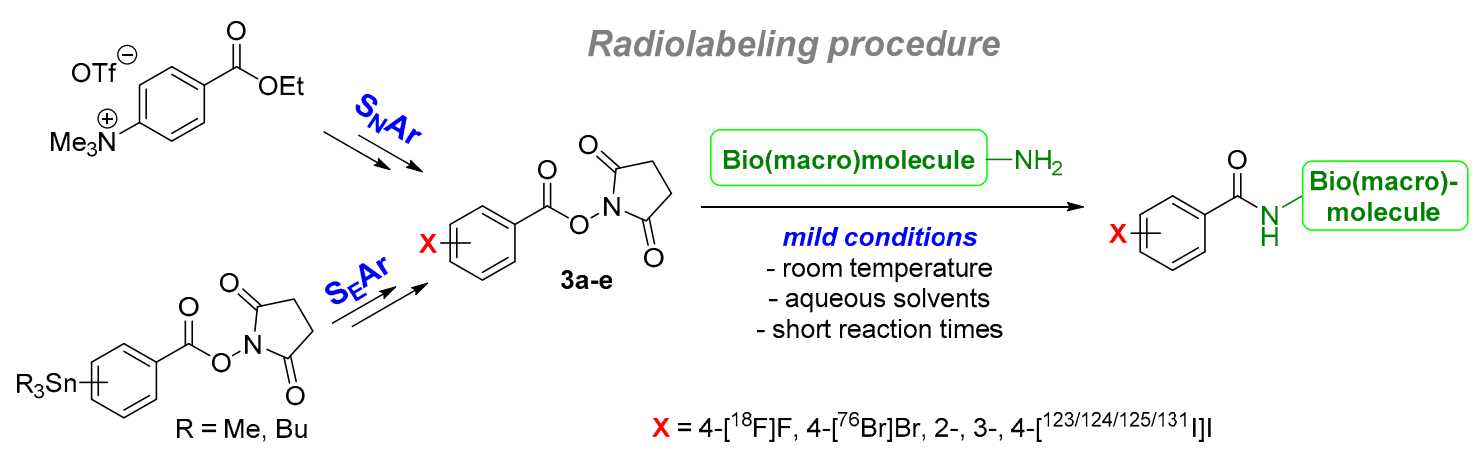

Scheme 1. General labeling procedure using radiolabeling building blocks based on radiohalogenated $\left({ }^{18} \mathrm{~F},{ }^{76} \mathrm{Br},{ }^{123 / 124 / 125 / 131} \mathrm{I}\right)$ succinimidyl benzoates.

Various ways to prepare the halogenated succinimidyl esters are known from the literature. Several are based on the Steglich esterification of $N$-hydroxy succinimide with the halobenzoic acid and DCC, EDC or TSTU as coupling reagent [11,29-33]. Others used halobenzyl alcohols under radical conditions [34,35] or halobenzoic acid and $N, N^{\prime}$-succinimidyl carbonate [36]. Transition metal catalyzed reactions are also applied such as palladium catalyzed coupling reactions with CO [37] or with formyl derivatives [38] as well as Ru-catalyzed reactions using the respective benzaldehyde [39].

Application of halobenzoyl chlorides or the use of the Steglich esterification are the most convenient synthesis methods with the highest yields and the shortest reaction times. In our case, the synthesis of all succinimidyl esters was accomplished using $N$-hydroxy succinimide (2) which was treated with the respective halobenzoyl chlorides (1a-e) in anhydrous THF and triethylamine as base [16]. All succinimidyl esters 3a-e were obtained in high yields of $77 \%$ to $92 \%$. The purification of 3a-e was accomplished via a short column chromatography. The reaction path is outlined in Scheme 2 .<smiles>[X]c1ccc(C(=O)Cl)cc1</smiles><smiles>[X]c1ccc(C(=O)ON2C(=O)CCC2=O)cc1</smiles>

a: $X=4-F$
b: $X=4-C I$
c: $X=4-B r$
d: $X=2-I$
e: $X=4-I$

Scheme 2. Synthesis path to the succinimidyl halobenzoates $\mathbf{3 a - e .}$

\subsection{X-ray Structure Determination}

Single crystals of $3 \mathbf{a}$ to $3 \mathbf{e}$ were obtained by the slow evaporation method. The crystal and experimental as well as the structure refinement parameters for the single crystal X-ray structure determinations are summarized in Table 1. The crystals of all five compounds consist of neutral succinimidyl halobenzoate molecules. The chloro-, bromo- and iodo-derivatives $\mathbf{3 b}, \mathbf{3} \mathbf{c}$ and $\mathbf{3 d}$, which rhave the halogen atom attached on the para-position of the benzoate ring, are isotypic. Figures 1-3 show the molecular structures of the five compounds. 
Table 1. Crystal data and structure refinement for compounds 3a-e.

\begin{tabular}{|c|c|c|c|c|c|}
\hline Parameter & $3 a$ & $3 b$ & $3 c$ & $3 d$ & $3 \mathbf{e}$ \\
\hline Formula & $\mathrm{C}_{11} \mathrm{H}_{8} \mathrm{FNO}_{4}$ & $\mathrm{C}_{11} \mathrm{H}_{8} \mathrm{ClNO}_{4}$ & $\mathrm{C}_{11} \mathrm{H}_{8} \mathrm{BrNO}_{4}$ & $\mathrm{C}_{11} \mathrm{H}_{8} \mathrm{INO}_{4}$ & $\mathrm{C}_{11} \mathrm{H}_{8} \mathrm{INO}_{4}$ \\
\hline Formula weight $\left(\mathrm{g} \cdot \mathrm{mol}^{-1}\right)$ & 237.18 & 253.63 & 298.09 & 345.08 & 345.08 \\
\hline Temperature $(\mathrm{K})$ & & & 123 & & \\
\hline Wavelength (̊̊) & & & 0.71073 & & \\
\hline Crystal system & monoclinic & monoclinic & monoclinic & monoclinic & orthorhombic \\
\hline Space group & $P 2_{1} / c$ & $P 2_{1} / n$ & $P 2_{1} / n$ & $P 2_{1} / n$ & Pbca \\
\hline \multicolumn{6}{|l|}{ Unit cell dimensions } \\
\hline$a(\AA)$ & $11.6331(6)$ & $8.7157(7)$ & $8.554(2)$ & $8.566(3)$ & $12.1900(3)$ \\
\hline$b(\AA)$ & $5.4971(3)$ & $5.7238(5)$ & $5.800(1)$ & $5.817(2)$ & $8.5246(2)$ \\
\hline$c(\AA)$ & $17.041(1)$ & $22.598(2)$ & $22.844(6)$ & $23.374(8)$ & $22.0618(6)$ \\
\hline$\beta\left(^{\circ}\right)$ & 103.992(2) & $90.470(4)$ & $92.20(1)$ & $93.27(2)$ & 90.00 \\
\hline Volume $\left(\AA^{3}\right)$ & 1057.4(1) & $1127.3(2)$ & $1132.5(5)$ & $1162.8(7)$ & $2292.6(1)$ \\
\hline$Z$ & 4 & 4 & 4 & 4 & 8 \\
\hline Density (calcd.) $\left(\mathrm{g} \cdot \mathrm{cm}^{-3}\right)$ & 1.490 & 1.494 & 1.748 & 1.971 & 2.000 \\
\hline Absorpt. coeff. $\left(\mathrm{mm}^{-1}\right)$ & 0.12 & 0.34 & 3.64 & 2.76 & 2.76 \\
\hline $\mathrm{F}(000)$ & 488 & 520 & 592 & 664 & 1328 \\
\hline Crystal size $\left(\mathrm{mm}^{3}\right)$ & $0.05 \times 0.05 \times 0.01$ & $0.22 \times 0.11 \times 0.06$ & $0.62 \times 0.40 \times 0.21$ & $0.15 \times 0.15 \times 0.10$ & \\
\hline Refinement method & \multicolumn{5}{|c|}{ Full matrix-least-squares } \\
\hline Data/restraints/param. & $2373 / 0 / 155$ & $5553 / 0 / 154$ & $9377 / 0 / 155$ & $10986 / 0 / 155$ & $4166 / 0 / 155$ \\
\hline Measured reflections & 19468 & 25796 & 67515 & 100672 & 38241 \\
\hline $2 \theta_{\max }\left({ }^{\circ}\right)$ & 27.3 & 36.6 & 45.4 & 47.9 & 33.1 \\
\hline$R_{\text {int }}$ & 0.124 & 0.042 & 0.106 & 0.034 & 0.063 \\
\hline GoF on $F^{2}$ & 1.11 & 1.05 & 1.05 & 1.13 & 1.16 \\
\hline $\mathrm{R} 1[I>2 \sigma(I)]$ & 0.054 & 0.044 & 0.050 & 0.030 & 0.025 \\
\hline$w R 2$ (all data) & 0.133 & 0.128 & 0.144 & 0.067 & 0.064 \\
\hline Larg. diff. peak/hole $\left(\mathrm{e} \cdot \AA^{3}\right)$ & $0.28 /-0.22$ & $0.64 /-0.66$ & $1.88 /-1.65$ & $2.82 /-2.34$ & $0.76 /-1.49$ \\
\hline
\end{tabular}
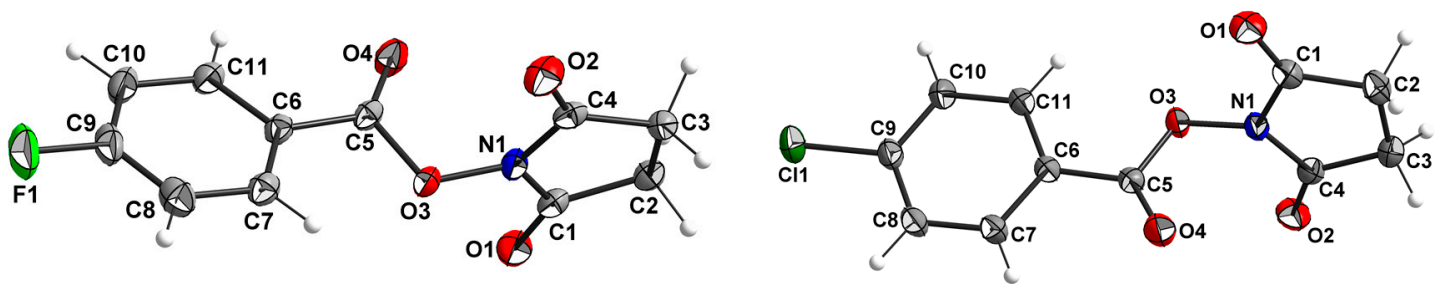

Figure 1. A view of the molecular structures of $\mathbf{3 a}$ (left) and $\mathbf{3 b}$ (right), showing the atom labeling scheme. Displacement ellipsoids are drawn at the $50 \%$ probability level.
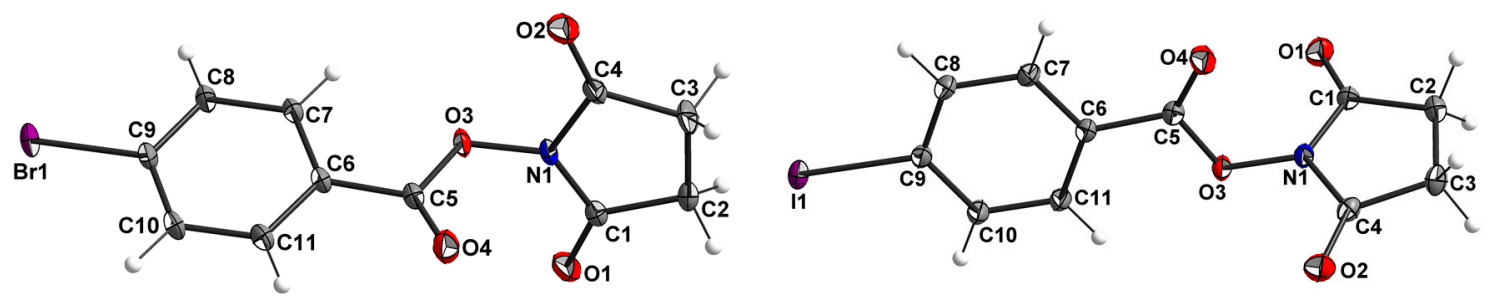

Figure 2. A view of the molecular structures of $3 \mathbf{c}$ (left) and $\mathbf{3 d}$ (right), showing the atom labeling scheme. Displacement ellipsoids are drawn at the $50 \%$ probability level.

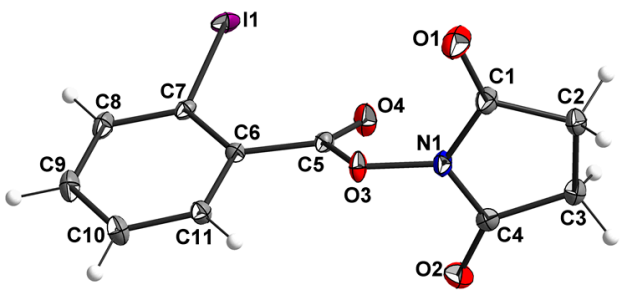

Figure 3. The molecular structure of $3 \mathbf{e}$ with the atom labeling scheme. Displacement ellipsoids are drawn at the $50 \%$ probability level. 
The interatomic distances for all five compounds are found within the expected ranges. Selected atom distances and mean plane angles are listed in Table 2. A different packing of the molecules is observed only in crystals of the fluoro compound $\mathbf{3 a}$ and the ortho-iodobenzoate $3 \mathbf{e}$, resulting in different space groups. The two carbon-oxygen bonds of $\mathrm{C} 5$ in all five structures differ significantly in length. Generally, the much shorter $\mathrm{C} 5-\mathrm{O} 4$ lengths compared to $\mathrm{C} 5-\mathrm{O} 3$ indicate a strong double bond character and a single bond character for $\mathrm{C} 5-\mathrm{O} 3$. The mean planes through the halo benzoate moieties are tilted towards the mean planes through the succinimidyl moieties by angles ranging from $70.7^{\circ}(3 \mathrm{c})$ to $80.5^{\circ}$ (3d), such that the two ring systems are arranged almost perpendicular to each other. Because of the lack of acidic protons, no classical hydrogen bonds are observed in the structures (see below).

Table 2. Selected atom distances $[\AA ̊]$ and mean plane angles $\left[^{\circ}\right]$.

\begin{tabular}{cccccc}
\hline Distance or Angle & 3a & 3b & 3c & 3d & 3e \\
\hline C=O carbonyl $[\AA]$ & $1.189(3)$ & $1.187(1)$ & $1.191(1)$ & $1.196(2)$ & $1.195(1)$ \\
C-O carbonyl $[\AA]$ & $1.389(2)$ & $1.392(1)$ & $1.398(1)$ & $1.395(2)$ & $1.400(1)$ \\
C=O succin. $($ av. $)[\AA]$ & 1.200 & 1.206 & 1.209 & 1.202 & 1.208 \\
C-Hal $[\AA]$ & $1.356(3)$ & $1.737(1)$ & $1.893(1)$ & $2.094(1)$ & $2.095(1)$ \\
$\varangle$ mean plane $\left[{ }^{\circ}{ }^{\text {] }}\right.$ (halobenzoyl/succinimidyl residues) & 76.2 & 72.9 & 70.7 & 80.5 & 71.6 \\
\hline
\end{tabular}

Furthermore, the surrounding of the nitrogen atoms of the succinimidyl residue in compounds 3a-e can be described as follows. These atoms show nearly planar bonding geometry, with a maximum deviation of $0.08 \AA$ out of the $\mathrm{C} 1-\mathrm{C} 4-\mathrm{O} 3$ plane. The presence of an adjacent single bound oxygen atom can act to pyramidalize the $\mathrm{N}$ bonding geometries, but in these cases it is minimal due to the strong conjugation between the $\mathrm{N}$ atom and two carbonyl groups. This nearly planar behavior can be explained by the partial double bond character of the N1-C1-O1 and the N1-C4-O2 amide function.

Figure 4 demonstrates exemplarily the packing of the molecules of $3 \mathbf{b}$ in a view along the $b$ axis of the unit cell. The dotted lines included in the figure show the shortest center distances of the phenyl rings (brown dotted lines) and the shortest intermolecular O....H distances (green dotted lines). Weak $\pi-\pi$ interactions with distances between the planes of the aromatic phenyl rings of $4.181 \AA$ and $4.586 \AA$ as well as weak "non-classical" hydrogen bonds with the shortest acceptor-donor distance of 3.264(1) $\AA$ (in 3b) are responsible for the final arrangement of molecules.

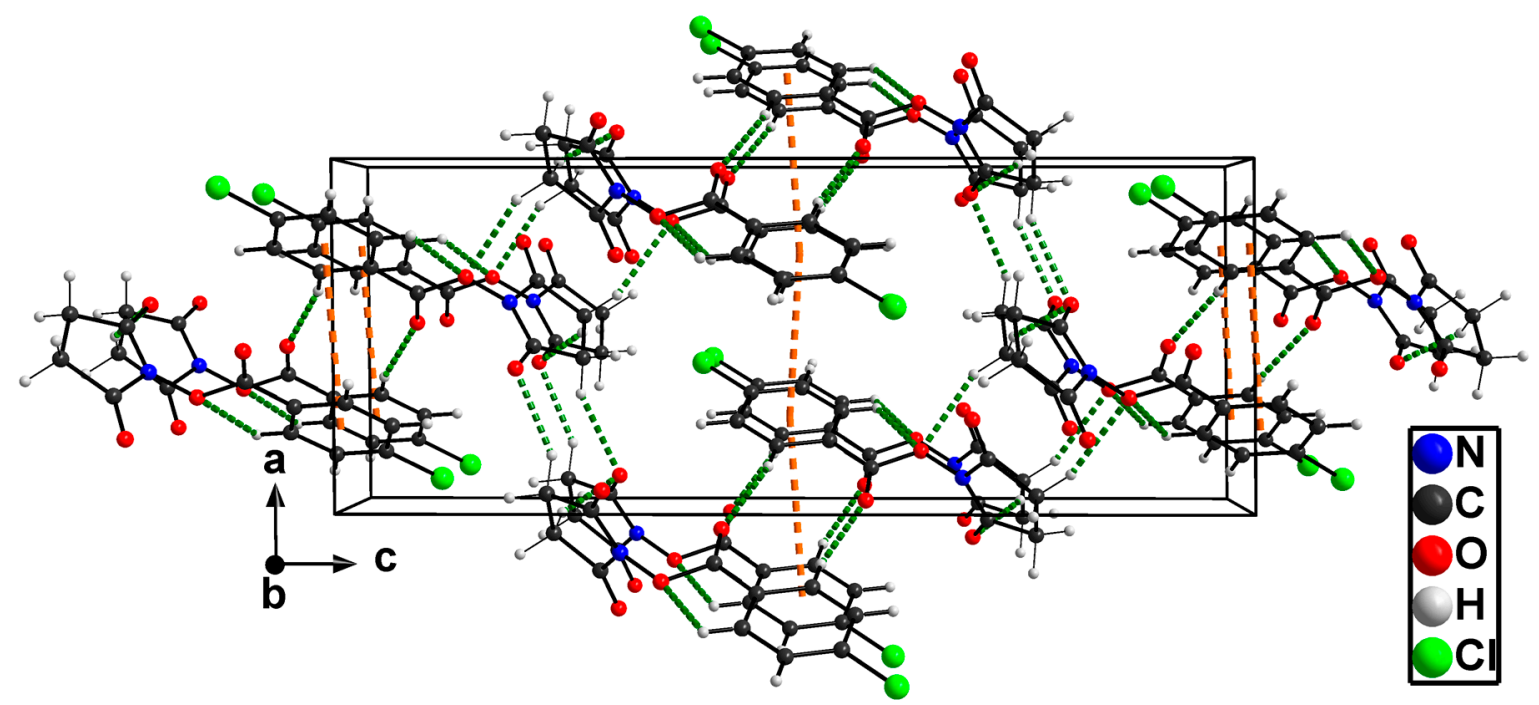

Figure 4. The packing of the molecules of $\mathbf{3 b}$ in an expanded view of the unit cell along the $b$ axis. The shortest contacts between the phenyl rings are shown as brown dotted lines and the shortest intermolecular O....H distances as green dotted lines. 


\section{Conclusions}

In this paper, we have synthesized four succinimidyl halobenzoate derivatives which are used in radiopharmacy as prostetic groups with the respective halo radionuclides. The structures of all derivatives were elucidated.

\section{Experimental Section}

\subsection{General}

NMR spectra were recorded on an Agilent DD2 (400 or $600 \mathrm{MHz})$ with ProbeOne probe. Chemical shifts of the ${ }^{1} \mathrm{H},{ }^{13} \mathrm{C}$ and ${ }^{19} \mathrm{~F}$ spectra were reported in parts per million (ppm) using TMS for ${ }^{1} \mathrm{H}$ and ${ }^{13} \mathrm{C}$ spectra and $\mathrm{CFCl}_{3}$ for ${ }^{19} \mathrm{~F}$ spectra as internal standard. Chromatographic separations and TLC detections were carried out with Merck Silica Gel $60(63-200 \mu \mathrm{m})$ and Merck Silica Gel $60 \mathrm{~F}_{254}$ sheets, respectively. TLCs were developed by visualization under UV light $(\lambda=254 \mathrm{~nm})$. Anhydrous THF was purchased from Acros (Geel, Belgium) or SigmaAldrich (Schnelldorf, Germany). $\mathrm{N}$-Hydroxysuccinimide (2), all benzoyl chlorides 1a-e and $\mathrm{Et}_{3} \mathrm{~N}$ were used as received without further purification. Crystallographic data were collected with a Bruker-Nonius Apex-X8 CCD-diffractometer (Bruker, Madison, WI, USA) with Mo-K $\mathrm{K}_{\alpha}$ radiation $(\lambda=0.71073 \AA$ ) at $123 \mathrm{~K}$. The structures were solved by direct methods using SHELXS-97 and refined against $F^{2}$ on all data by full matrix least-squares refinements using the program suites from G. M. Sheldrick [40-42]. Data corrections including multi-scan absorption corrections were applied to the data sets using the Bruker AXS software [43]. All non-hydrogen atoms were refined anisotropically; all hydrogen atoms bonded to $C$ atoms were placed on geometrically calculated positions and refined using riding models. CCDC 1524925 (3a), CCDC 1504220 (3b), CCDC 1505323 (3c), CCDC 1505325 (3d), and CCDC 1505324 (3e) contain the supplementary crystallographic data of the compounds. These data can be obtained free of charge from The Cambridge Crystallographic Data Centre via http://www.ccdc.cam.ac.uk/conts/retrieving.html.

\subsection{General Synthesis Procedure}

$\mathrm{N}$-Hydroxysuccinimide $(2,150 \mathrm{mg}, 1.33 \mathrm{mmol})$ was dissolved in anhydrous THF (10 mL), $\mathrm{Et}_{3} \mathrm{~N}(197 \mathrm{mg}, 1.95 \mathrm{mmol})$ was added and the mixture was cooled to $0{ }^{\circ} \mathrm{C}$. Next, the respective halobenzoyl chloride $1 \mathrm{a}-\mathbf{e}(1.56 \mathrm{mmol})$ was added dropwise, the solution was stirred at $0{ }^{\circ} \mathrm{C}$ for $60 \mathrm{~min}$ and at $\mathrm{rt}$ for $2 \mathrm{~h}$. Afterwards, the reaction was quenched with water $(15 \mathrm{~mL})$ and extracted with ethyl acetate $(3 \times 15 \mathrm{~mL})$. The combined organic layers were separated and dried over $\mathrm{Na}_{2} \mathrm{SO}_{4}$. The solvent was removed and the crude product was purified via flash chromatography (petroleum ether/ethyl acetate $2: 1)$ to yield compounds $3 \mathbf{a}-\mathbf{e}(77 \%-92 \%)$ as colorless solids.

\subsubsection{Succinimidyl 4-Fluorobenzoate (SFB, 3a)}

Yield: $283 \mathrm{mg}, 92 \%$. M.p. $112{ }^{\circ} \mathrm{C} .{ }^{1} \mathrm{H}$ NMR $\left(400 \mathrm{MHz}, \mathrm{CDCl}_{3}\right): \delta=2.90\left(\mathrm{~s}, 4 \mathrm{H}, \mathrm{CH}_{2}\right)$, $7.19\left(\mathrm{t},{ }^{3} \mathrm{~J}=\mathrm{Hz}, \mathrm{Ar}-\mathrm{H}\right), 8.16\left(\mathrm{dd},{ }^{3} \mathrm{~J}=\mathrm{Hz},{ }^{3} \mathrm{~J}_{\mathrm{H}, \mathrm{F}}=\mathrm{Hz}, 2 \mathrm{H}, \mathrm{Ar}-\mathrm{H}\right) ;{ }^{13} \mathrm{C}$ NMR $\left(101 \mathrm{MHz}, \mathrm{CDCl}_{3}\right)$ : $\delta=25.8\left(\mathrm{CH}_{2}\right), 116.4\left(\mathrm{~d},{ }^{2} J_{\mathrm{C}, \mathrm{F}}=22.3 \mathrm{~Hz}, \mathrm{C}-\mathrm{H}_{\text {meta }}\right), 121.5\left(\mathrm{~d},{ }^{4} J_{\mathrm{C}, \mathrm{F}}=3.2 \mathrm{~Hz}, \mathrm{C}_{\mathrm{ipso}}\right) 133.5\left(\mathrm{~d},{ }^{3} J_{\mathrm{C}, \mathrm{F}}=9.9 \mathrm{~Hz}\right.$, $\left.\mathrm{C}-\mathrm{H}_{\text {ortho }}\right), 161.0(\mathrm{C}=\mathrm{O}), 167.0\left(\mathrm{~d},{ }^{1} \mathrm{~J}_{\mathrm{C}, \mathrm{F}}=257.6 \mathrm{~Hz}, \mathrm{C}_{\text {para }}\right), 169.3(\mathrm{C}=\mathrm{O}) ;{ }^{19} \mathrm{~F}$ NMR $\left(376 \mathrm{MHz}, \mathrm{CDCl}_{3}\right)$ : $\delta=-101.3 \mathrm{ppm}$.

\subsubsection{Succinimidyl 4-Chlorobenzoate (SClB, $3 \mathbf{b})$}

Yield: $290 \mathrm{mg}, 88 \%$. M.p. $206{ }^{\circ} \mathrm{C} .{ }^{1} \mathrm{H}$ NMR $\left(600 \mathrm{MHz}, \mathrm{CDCl}_{3}\right): \delta=2.91\left(\mathrm{~s}, 4 \mathrm{H}, \mathrm{CH}_{2}\right)$, $7.50\left(\mathrm{~d},{ }^{3} \mathrm{~J}=8.6 \mathrm{~Hz}, \mathrm{H}_{\text {meta }}\right), 8.07\left(\mathrm{~d},{ }^{3} \mathrm{~J}=8.6 \mathrm{~Hz}, \mathrm{H}_{\text {ortho }}\right) ;{ }^{13} \mathrm{C} \mathrm{NMR}\left(151 \mathrm{MHz}, \mathrm{CDCl}_{3}\right): \delta=25.8\left(\mathrm{CH}_{2}\right)$, $123.7\left(\mathrm{C}_{\mathrm{ipso}}\right), 129.5\left(\mathrm{C}_{\text {meta }}\right), 132.0\left(\mathrm{C}_{\text {ortho }}\right), 141.8\left(\mathrm{C}_{\text {para }}\right), 161.3(\mathrm{C}=\mathrm{O}), 169.2\left(\mathrm{C}=\mathrm{O}_{\text {succ }}\right)$. 


\subsubsection{Succinimidyl 4-Bromobenzoate ( $\mathrm{SBrB}, 3 \mathrm{c})$}

Yield: $300 \mathrm{mg}, 77 \%$. M.p. $224{ }^{\circ} \mathrm{C} .{ }^{1} \mathrm{H}$ NMR $\left(600 \mathrm{MHz}, \mathrm{CDCl}_{3}\right): \delta=2.91\left(\mathrm{~s}, 4 \mathrm{H}, \mathrm{CH}_{2}\right)$, $7.67\left(\mathrm{~d},{ }^{3} \mathrm{~J}=8.6 \mathrm{~Hz}, \mathrm{H}_{\text {meta }}\right), 8.56\left(\mathrm{~d},{ }^{3} \mathrm{~J}=8.6 \mathrm{~Hz}, \mathrm{H}_{\text {ortho }}\right) ;{ }^{13} \mathrm{C} \mathrm{NMR}\left(151 \mathrm{MHz}, \mathrm{CDCl}_{3}\right): \delta=25.8\left(\mathrm{CH}_{2}\right)$, $124.2\left(\mathrm{C}_{\text {para }}\right), 130.6\left(\mathrm{C}_{\text {ipso }}\right), 132.1,132.5\left(\mathrm{C}_{\text {meta }}+\mathrm{C}_{\text {ortho }}\right), 161.4(\mathrm{C}=\mathrm{O}), 169.2\left(\mathrm{C}=\mathrm{O}_{\text {succ }}\right)$.

\subsubsection{Succinimidyl 2-Iodobenzoate (o-SIB, 3d)}

Yield: $410 \mathrm{mg}, 91 \%$. M.p. $134{ }^{\circ} \mathrm{C} .{ }^{1} \mathrm{H}$ NMR $\left(600 \mathrm{MHz}, \mathrm{CDCl}_{3}\right): \delta=2.91\left(\mathrm{~s}, 4 \mathrm{H}, \mathrm{CH}_{2}\right)$, $7.28\left(\mathrm{dt}^{4} \mathrm{~J}=1.4 \mathrm{~Hz},{ }^{3} \mathrm{~J}=7.7 \mathrm{~Hz}, 1 \mathrm{H}, \mathrm{H}_{\mathrm{Ar}}\right), 7.48\left(\mathrm{t},{ }^{3} \mathrm{~J}=7.7 \mathrm{~Hz}, 1 \mathrm{H}, \mathrm{H}_{\mathrm{Ar}}\right), 8.08\left(\mathrm{~d},{ }^{3} \mathrm{~J}=8.0 \mathrm{~Hz}, \mathrm{H}_{\mathrm{Ar}}\right)$, $8.11\left(\mathrm{dd},{ }^{4} J=1.5 \mathrm{~Hz},{ }^{3} J=7.7 \mathrm{~Hz}, 1 \mathrm{H}, \mathrm{H}_{\mathrm{Ar}}\right) ;{ }^{13} \mathrm{C} \mathrm{NMR}\left(151 \mathrm{MHz}, \mathrm{CDCl}_{3}\right): \delta=25.9\left(\mathrm{CH}_{2}\right), 95.9\left(\mathrm{C}_{\mathrm{Ar}}\right)$, $128.3\left(\mathrm{CH}_{\mathrm{Ar}}\right), 129.5\left(\mathrm{C}_{\mathrm{Ar}}\right), 132.4\left(\mathrm{CH}_{\mathrm{Ar}}\right), 134.7\left(\mathrm{CH}_{\mathrm{Ar}}\right), 142.3\left(\mathrm{CH}_{\mathrm{Ar}}\right), 161.4(\mathrm{C}=\mathrm{O}), 169.1\left(\mathrm{C}=\mathrm{O}_{\text {succ }}\right)$.

\subsubsection{Succinimidyl 4-Iodobenzoate ( $p$-SIB, 3e)}

Yield: $402 \mathrm{mg}, 90 \%$. M.p. $162{ }^{\circ} \mathrm{C} .{ }^{1} \mathrm{H}$ NMR $\left(600 \mathrm{MHz}, \mathrm{CDCl}_{3}\right): \delta=2.91\left(\mathrm{~s}, 4 \mathrm{H}, \mathrm{CH}_{2}\right)$, $7.83\left(\mathrm{~d},{ }^{3} \mathrm{~J}=8.5 \mathrm{~Hz}, \mathrm{H}_{\text {ortho }}\right), 7.89\left(\mathrm{~d},{ }^{3} \mathrm{~J}=8.5 \mathrm{~Hz}, \mathrm{H}_{\text {meta }}\right) ;{ }^{13} \mathrm{C} \mathrm{NMR}\left(151 \mathrm{MHz}, \mathrm{CDCl}_{3}\right): \delta=25.8\left(\mathrm{CH}_{2}\right)$, $103.5\left(\mathrm{C}_{\text {para }}\right), 124.7\left(\mathrm{C}_{\mathrm{ipso}}\right), 131.8\left(\mathrm{C}_{\text {ortho }}\right), 138.5\left(\mathrm{C}_{\text {meta }}\right), 161.7(\mathrm{C}=\mathrm{O}), 169.2\left(\mathrm{C}=\mathrm{O}_{\text {succ }}\right)$.

Acknowledgments: Patrick Wieder (HZDR) is gratefully acknowledged for the support during the syntheses.

Author Contributions: Constantin Mamat performed the syntheses and the NMR analyses; Martin Köckerling and Daniel Holger Weiß performed the XRD experiments and analyzed the data; Constantin Mamat and Martin Köckerling contributed equally by writing the manuscript.

Conflicts of Interest: The authors declare no conflict of interest.

\section{References}

1. Jacobson, O.; Kiesewetter, D.O.; Chen, X. Fluorine-18 Radiochemistry, Labeling Strategies and Synthetic Routes. Bioconjug. Chem. 2015, 26, 1-18. [CrossRef] [PubMed]

2. Wester, H.J.; Schottelius, M. Fluorine-18 Labeling of Peptides and Proteins. In PET Chemistry The Driving Force in Molecular Imaging; Ernest Schering Research Foundation Workshop 61; Schubiger, P.A., Lehmann, L., Friebe, M., Eds.; Springer: Heidelberg, Germany, 2007; pp. 79-112.

3. Richter, S.; Wuest, F. ${ }^{18}$ F-Labeled Peptides: The Future Is Bright. Molecules 2014, 19, 20536-20556. [CrossRef] [PubMed]

4. Olberg, D.E.; Hjuelsten, O.K. Labeling strategies of peptides with ${ }^{18} \mathrm{~F}$ for positron emission tomography. Curr. Top. Med. Chem. 2010, 10, 1669-1679. [CrossRef] [PubMed]

5. Okarvi, S.M. Recent progress in fluorine-18 labelled peptide radiopharmaceuticals. Eur. J. Nucl. Med. 2001, 28, 929-938. [CrossRef] [PubMed]

6. Anderson, G.W. The use of activated esters in peptide synthesis. Metabolism 1964, 13, 1026-1031. [CrossRef]

7. Zalutsky, M.R.; Narula, A.S. A method for the radiohalogenation of proteins resulting in decreased thyroid uptake of radioiodine. Appl. Radiat. Isot. 1987, 38, 1051-1055. [CrossRef]

8. Garg, P.K.; Archer, G.E.; Bigner, D.D.; Zalutsky, M.R. Synthesis of radioiodinated N-succinimidyl iodobenzoate: Optimization for use in antibody labelling. Appl. Radiat. Isot. 1989, 40, 485-490. [CrossRef]

9. Koziorowski, J.; Henssen, C.; Weinreich, R. A new convenient route to radioiodinated N-succinimidyl 3- and 4-iodobenzoate, two reagents for radioiodination of proteins. Appl. Radiat. Isot. 1998, 49, 955-959. [CrossRef]

10. Vaidyanathan, G.; Zalutsky, M.R. Preparation of $N$-succinimidyl 3-[*I]iodobenzoate: An agent for the indirect radioiodination of proteins. Nat. Prot. 2006, 1, 707-713. [CrossRef] [PubMed]

11. Glaser, M.; Collingridge, D.R.; Aboagye, E.; Bouchier-Hayes, L.; Brown, D.J.; Hutchinson, O.C.; Martin, S.; Price, P.; Luthra, S.K.; Brady, F. Preparation of $\left[{ }^{124} \mathrm{I}\right] \mathrm{IBA}-\mathrm{annexin-V}$ as a potential pet probe for apoptosis. J. Label. Compd. Radiopharm. 2001, 44, S336-S338. [CrossRef]

12. Bourgeois, M.; Guerard, F.; Alliot, C.; Mougin-Degraef, M.; Rajerison, H.; Remaud-Le Saec, P.; Gestin, J.-F.; Davodeau, F.; Cherel, M.; Barbet, J.; et al. Feasibility of the radioastatination of a monoclonal antibody with astatine-211 purified by wet extraction. J. Label. Compd. Radiopharm. 2008, 51, 379-383. [CrossRef] [PubMed] 
13. Gifford, A.N.; Kuschel, S.; Shea, C.; Fowler, J.S. Polymer-Supported Organotin Reagent for Prosthetic Group Labeling of Biological Macromolecules with Radioiodine. Bioconjug. Chem. 2011, 22, 406-412. [CrossRef] [PubMed]

14. Rajerison, H.; Faye, D.; Roumesy, A.; Louaisil, N.; Boeda, F.; Faivre-Chauvet, A.; Gestin, J.-F.; Legoupy, S. Ionic liquid supported organotin reagents to prepare molecular imaging and therapy agents. Org. Biomol. Chem. 2016, 14, 2121-2126. [CrossRef]

15. Zlatopolskiy, B.D.; Morgenroth, A.; Urusova, E.A.; Dinger, C.; Kull, T.; Pape, M.; Glatting, G.; Reske, S.N. Towards to $\mathrm{hENT}_{1}$-nucleoside transporter selective imaging agents. Synthesis and in vitro evaluation of the radiolabeled SAENTA analogues. Bioorg. Med. Chem. Lett. 2009, 19, 5151-5154. [CrossRef]

16. Rossouw, D.D. Radioiodine labelling of a small chemotactic peptide, utilizing two different prosthetic groups: A comparative study. J. Label. Compd. Radiopharm. 2008, 51, 48-53. [CrossRef]

17. Dissoki, S.; Hagooly, A.; Elmachily, S.; Mishani, E. Labeling approaches for the GE11 peptide, an epidermal growth factor receptor biomarker. J. Label. Compd. Radiopharm. 2011, 54, 693-701. [CrossRef]

18. Wang, H.; Byun, Y.; Barinka, C.; Pullambhatla, M.; Bhang, H.-E.C.; Fox, J.J.; Lubkowski, J.; Mease, R.C.; Pomper, M.G. Bioisosterism of urea-based GCPII inhibitors: Synthesis and structure-activity relationship studies. Bioorg. Med. Chem. Lett. 2010, 20, 392-397. [CrossRef]

19. Yang, X.; Mease, R.C.; Pullambhatla, M.; Lisok, A.; Chen, Y.; Foss, C.A.; Wang, Y.; Shallal, H.; Edelman, H.; Hoye, A.T; et al. $\left[{ }^{18}\right.$ F]Fluorobenzoyllysinepentanedioic Acid Carbamates: New Scaffolds for Positron Emission Tomography (PET) Imaging of Prostate-Specific Membrane Antigen (PSMA). J. Med. Chem. 2016, 59, 206-218. [CrossRef]

20. Pérez-Medina, C.; Patel, N.; Robson, M.; Badar, A.; Lythgoe, M.F.; Årstad, E. Evaluation of a ${ }^{125}$ I-labelled benzazepinone derived voltage-gated sodium channel blocker for imaging with SPECT. Org. Biomol. Chem. 2012, 10, 9474-9480. [CrossRef]

21. Riss, P.J.; Lu, S.; Telu, S.; Aigbirhio, F.I.; Pike, V.W. Cu ${ }^{\mathrm{I}}$-Catalyzed ${ }^{11} \mathrm{C}$ Carboxylation of Boronic Acid Esters: A Rapid and Convenient Entry to ${ }^{11}$ C-Labeled Carboxylic Acids, Esters, and Amides. Angew. Chem. Int. Ed. 2012, 51, 2698-2702. [CrossRef]

22. Yngve, U.; Hedberg, E.; Tolmachev, V.; Långström, B. Synthesis of N-succinimidyl-4-[ $\left.{ }^{76} \mathrm{Br}\right]$ bromobenzoate and its use in conjugation to proteins and 5'-modified oligonucleotides. J. Label. Compd. Radiopharm. 1997, 40, 120-121.

23. Yngve, U.; Hedberg, E.; Lövqvist, A.; Tolmachev, V.; Långström, B. Synthesis of N-Succinimidyl $4-\left[{ }^{76} \mathrm{Br}\right]$ Bromobenzoate and its Use in Conjugation Labelling of Macromolecules. Acta Chem. Scand. 1999, 53, 508-512. [CrossRef]

24. Mäding, P.; Füchtner, F.; Wüst, F. Module-assisted synthesis of the bifunctional labelling agent $N$-succinimidyl 4- $\left[{ }^{18} \mathrm{~F}\right]$ fluorobenzoate ( $\left.\left[{ }^{18} \mathrm{~F}\right] \mathrm{SFB}\right)$. Appl. Radiat. Isot. 2005, 63, 329-332. [CrossRef]

25. Shao, X. Synthesis of $N$-succinimidyl $4-\left[{ }^{18} \mathrm{~F}\right]$ fluorobenzoate $\left(\left[{ }^{18} \mathrm{~F}\right] \mathrm{SFB}\right)$. In Radiochemical Syntheses, Radiopharmaceuticals for Positron Emission Tomography; Scott, P.J.H., Hockley, B.G., Eds.; Wiley: Hoboken, NJ, USA, 2011; pp. 81-86.

26. Carroll, M.; Yan, R.; Aigbirhio, F.; Soloviev, D.; Brichard, L. Single-step synthesis of N-succinimidyl-4$\left[{ }^{18}\right.$ F]fluorobenzoate. J. Nucl. Med. 2008, 49, 298.

27. Chun, J.-H.; Pike, V.W. Single-step syntheses of no-carrier-added functionalized $\left[{ }^{18} \mathrm{~F}\right]$ fluoroarenes as labeling synthons from diaryliodonium salts. Org. Biomol. Chem. 2013, 11, 6300-6306. [CrossRef]

28. Lee, E.; Hooker, J.M.; Ritter, T. Nickel-Mediated Oxidative Fluorination for PET with Aqueous $\left[{ }^{18}\right.$ F] Fluoride. J. Am. Chem. Soc. 2012, 134, 17456-17458. [CrossRef]

29. Vangveravong, S.; Xu, J.; Zeng, C.; Mach, R.H. Synthesis of N-substituted 9-azabicyclo[3.3.1]nonan-3 $\alpha$-yl carbamate analogs as $\sigma 2$ receptor ligands. Bioorg. Med. Chem. 2006, 14, 6988-6997. [CrossRef]

30. Chen, J.; Wu, W.; McNeil, A.J. Detecting a peroxide-based explosive via molecular gelation. Chem. Commun. 2012, 48, 7310-7312. [CrossRef]

31. Kim, D.H.; Blacker, M.; Valliant, J.F. Preparation and Evaluation of Fluorine-18-Labeled Insulin as a Molecular Imaging Probe for Studying Insulin Receptor Expression in Tumors. J. Med. Chem. 2014, 57, 3678-3686. [CrossRef] 
32. Matusiak, N.; Castelli, R.; Tuin, A.W.; Overkleeft, H.S.; Wisastra, R.; Dekker, F.J.; Prly, L.M.; Bischoff, R.P.M.; van Waarde, A.; Dierckx, R.A.J.O.; et al. A dual inhibitor of matrix metalloproteinases and a disintegrin and metalloproteinases. $\left[{ }^{18} \mathrm{~F}\right] \mathrm{FB}-\mathrm{ML} 5$, as a molecular probe for non-invasive MMP/ADAM-targeted imaging. Bioorg. Med. Chem. 2015, 23, 192-202. [CrossRef]

33. Sotgiu, G.; Galeotti, M.; Samori, C.; Bongini, A.; Mazzanti, A. Push-Pull Amino Succinimidyl Ester Thiophene-Based Fluorescent Dyes: Synthesis and Optical Characterization. Chem. Eur. J. 2011, 17, 7947-7952. [CrossRef]

34. Wang, N.; Liu, R.; Xu, Q.; Liang, X. N-Hydroxysuccinimide-promoted Oxidation of Primary Alcohols and Aldehydes to Form Active Esters with Hypervalent(III) Iodine. Chem. Lett. 2006, 35, 566-567.

35. Wang, G.; Yu, Q.-Y.; Wang, J.; Wang, S.; Chen, S.-Y.; Yu, X.-Q. Iodide-catalyzed amide synthesis from alcohols and amines. RSC Adv. 2013, 3, 21306-21310. [CrossRef]

36. Azarian, V.; Gangloff, A.; Seimbille, Y.; Delaloye, S.; Czernin, J.; Phelps, M.E.; Silverman, D.H.S. Synthesis and liposome encapsulation of a novel ${ }^{18} \mathrm{~F}$-conjugate of $\omega$-conotoxin GVIA for the potential imaging of $\mathrm{N}$-type $\mathrm{Ca}^{2+}$ channels in the brain by positron emission tomography. J. Label. Compd. Radiopharm. 2006, 49, 269-283. [CrossRef]

37. De Almeida, A.M.; Andersen, T.L.; Lindhardt, A.T.; de Almeida, M.V.; Skrydstrup, T. General Method for the Preparation of Active Esters by Palladium-Catalyzed Alkoxycarbonylation of Aryl Bromides. J. Org. Chem. 2015, 80, 1920-1928. [CrossRef]

38. Barr, A.; Tnta, M.-L.; Alix, F.; Gembus, V.; Papamical, C.; Levacher, V. Palladium-Catalyzed Carbonylation of (Hetero)Aryl, Alkenyl and Allyl Halides by Means of N-Hydroxysuccinimidyl Formate as CO Surrogate. J. Org. Chem. 2015, 80, 6537-6544. [CrossRef]

39. Dinda, M.; Bose, C.; Ghosh, T.; Maity, S. Cross dehydrogenative coupling (CDC) of aldehydes with $\mathrm{N}$-hydroxyimides by visible light photoredox catalysis. RSC Adv. 2015, 5, 44928-44932. [CrossRef]

40. Sheldrick, G.M. A short history of SHELX. Acta Cryst. 2008, A64, 112-122. [CrossRef]

41. Scheldrick, G.M. Crystal structure refinement with SHELXL. Acta Cryst. 2015, C71, 3-8.

42. Sheldrick, G.M. SHELXL 2014/1; University of Göttingen: Göttingen, Germany, 2014.

43. Bruker AXS Inc. APEX-II (ver. 2008.1-0), SAINT (ver. 7.51A) and SADABS (ver. 2007/4); Bruker AXS Inc.: Madison, WI, USA, 2008.

(C) 2017 by the authors. Licensee MDPI, Basel, Switzerland. This article is an open access article distributed under the terms and conditions of the Creative Commons Attribution (CC BY) license (http:/ / creativecommons.org/licenses/by/4.0/). 